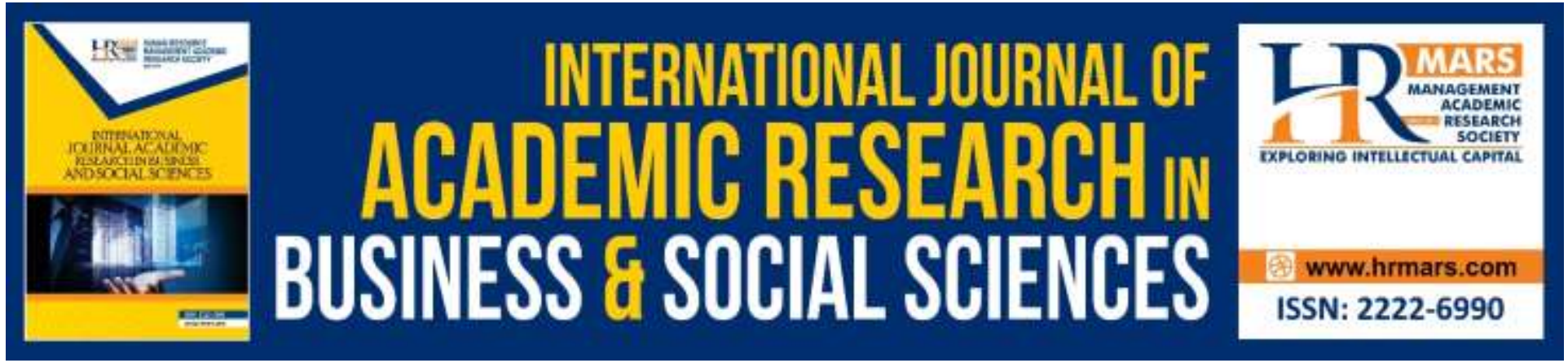

\title{
Malaysian Educational Leaders: The Conceptual Frameworks
}

\author{
Noor Fazilah Binti Ahmad Jamli and Syed Sofian Bin Syed Salim
}

To Link this Article: http://dx.doi.org/10.6007/IJARBSS/v9-i7/6198

DOI: $10.6007 /$ IJARBSS/v9-i7/6198

Received: 15 May 2019, Revised: 25 June 2019, Accepted: 01 July 2019

Published Online: 24 July 2019

In-Text Citation: (Jamli \& Salim, 2019)

To Cite this Article: Jamli, N. F. B. A., \& Salim, S. S. B. S. (2019). Malaysian Educational Leaders: The Conceptual Frameworks. International Journal of Academic Research in Business and Social Sciences, 9(7), 994-998.

Copyright: (C) 2019 The Author(s)

Published by Human Resource Management Academic Research Society (www.hrmars.com)

This article is published under the Creative Commons Attribution (CC BY 4.0) license. Anyone may reproduce, distribute, translate and create derivative works of this article (for both commercial and non-commercial purposes), subject to full attribution to the original publication and authors. The full terms of this license may be seen at: http://creativecommons.org/licences/by/4.0/legalcode

\section{Vol. 9, No. 7, 2019, Pg. 994 - 998}

Full Terms \& Conditions of access and use can be found at http://hrmars.com/index.php/pages/detail/publication-ethics 


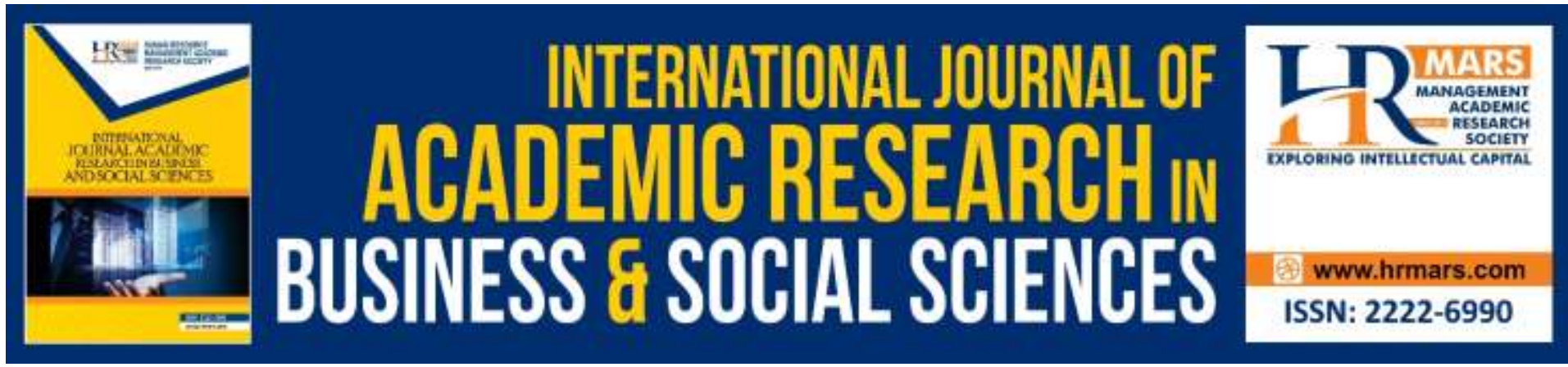

\title{
Malaysian Educational Leaders: The Conceptual Frameworks
}

\section{Noor Fazilah Binti Ahmad Jamli and Syed Sofian Bin Syed Salim}

Faculty of Education and Human Development, Sultan Idris Education University, 35900 Tanjong Malim, Perak, Malaysia

Email: aininatashanajwa@gmail.com

\begin{abstract}
The purpose of this article is to highlight the importance of emotional intelligence in educational leadership and its relations towards principal's leadership style of secondary school in Malaysia and impacts on school performance based on SelfAssessment Band of Malaysia Education Quality Standards (Ministry of Education). In recent years there has been an increasing interest regarding emotional intelligence and its role in headmaster's leadership style. In multidisciplinary area, emotional intelligence is considered as an important component and play and important role in leadership. However, too little attention has been made educational leaders especially in Malaysian context of view. Hence this article seeks to highlight the conceptual frameworks with emotional intelligence as the important element in educational leadership.
\end{abstract}

Keywords: Emotional Intelligence, Leadership Style, School Performance, Assessment

\section{Emotional Intelligence Role}

Headmaster's role and challenges give impact towards their capability and ability in leading the organization. Leader selection system in leading education organization in Malaysia back then was based on automatic appointment and service duration or officer's seniority (MOE, 2014). Furthermore, the main changes in Malaysia educational system are headmaster's leadership management at school (Nazri, 2012).

Malaysia Education Blueprint 2013-2025 have enhances effort on Fifth Shift in Malaysian Education Development Plan 2013-2025 is to ensure Malaysian schools lead by high prestige Principal and Headmaster (MOE, 2013). Leadership seems to be important and turning point differences between successful organization or not (Sarvinder \& Ahmad, 2008). Supported by Amin (2012), whereby empirically shows leader's role in an important factor in determining effectiveness and quality of school which successfully lead by compatible leader. 
In previous leadership research done in West Country, those who succeed in leadership and management are associated with emotional intelligence (Stokely, 2008). Leaders with highly emotional intelligence able to adapt them with working environment which they can manage conflict (Hopkins \& Yonker, 2015). Wendor-heldt \& Kay (2009) conclude that highly emotional intelligence leader's success in leading organization and used in Singapore's school leadership system (Koh, Steers \& Terborg, 1995; Sagnak, 2010).

\section{Transformational Leadership Style}

Stokely (2008) founds that most leadership failures is due to deterioration of emotional competency. Study by Naseer, Chishti, Rahman and Jumani (2011) leaders who demonstrate high emotional intelligence are more optimistic about their work by demonstrating positive behaviors leads to low job satisfaction and high job performance. Similarly in Tang, Yin and Nelson (2010), evidence suggested that leaders with high emotional intelligence tend to practice transformational leader styles. Sidhu and Fook (2005) agreed that there are possibilities that effective transformational leadership styles would enhance school's performance. Study by Ishak (2002) shows that leadership styles favors by lower class is transformational leadership and most preferred by organization members by $72 \%$ to $82 \%$ compared to transactional leadership.

According to Mazlan (2002) stated that transformational leadership studies in Malaysian school is still lacking. He founds that transformation leadership studies scientifically new and leadership styles has not been studied by local and international researchers. Study conducted by Ghani and Anandan (2013) on leadership influences which is instructional and transformational leadership towards student performance tends to change attitude, behavior and thinking positively affects students and researchers as well as transformational leadership for improving student's performance indirectly.

\section{School Performance}

School effectiveness measured by success and performance in examination. A school that does not achieve high academic level is categorized as less effective school (Tabor, 1998). In relation with transformation of education system, MOE emphasize "Effective Principal and Effective School" practice as restructuring educational organization agenda (Sani \& Zaiton, 2001). In Malaysia educational system, school grading system is based on Malaysia Education Quality Standards using Effective School Model from Sammons, Hillman \& Mortimore 1995 and Inspecting Student Outcome Model (MOE, 2010). Based on schools quality and performance wholly doesn't only depend on teaching and learning process quality, student product but also based on management and leadership management interest. There are five standard from the performance standard which measured school performance's level and have few criteria each relates to one another seen as critical factor of quality indicator. 


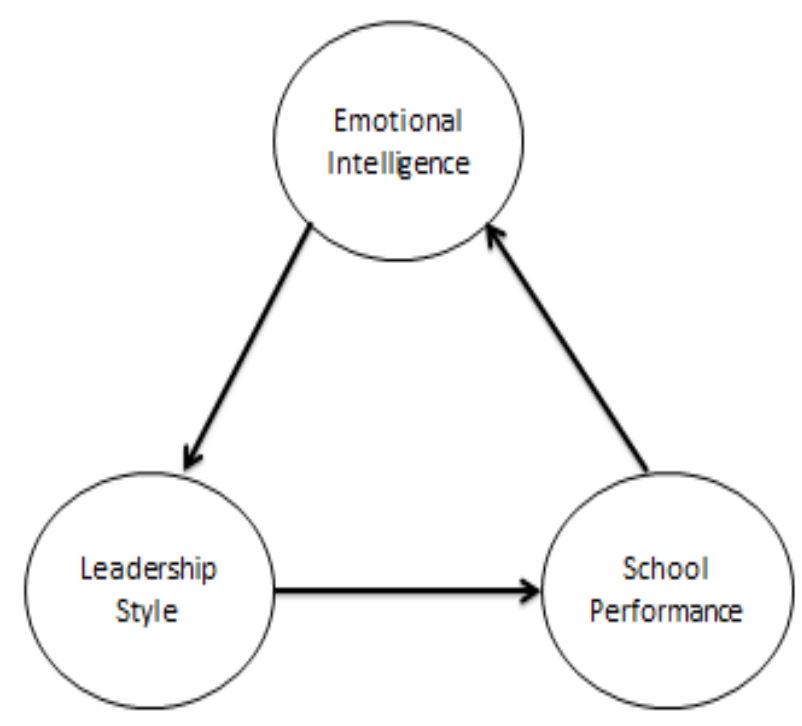

Figure 1. Conceptual Framework of Emotional Intelligence and Leadership Style towards School Performance.

\section{Conclusion}

In conclusion, schools that are classified as successful are led by highly qualified leaders and vice versa. Thus, leaders with high emotional intelligence are able to adapt to the working environment that enables them to manage any conflict and make the difference between high-performing schools and low-performing schools. Leadership factors are seen as important and serve as a turning point for differences between successful organization or otherwise (Sarvinder and Ahmad, 2008). Empirically study shows that the role of leaders is an important factor in determining the quality and the effectiveness of schools (Amin, 2012) and leaders with high emotional intelligence were found to be successful in leading the organization.

\section{Corresponding Author}

Noor Fazilah Ahmad Jamli

Faculty of Education and Human Development, Sultan Idris Education University, 35000 Tanjung Malim

Perak, Malaysia.

\section{References}

Ahmad, Esa, \& Savinder, S. (2008). National Education Management Seminar PKPGB 2008 , 16. In Facing New Education Issues Leadership.

Ghani, A. \& Anandan, K. (2013). The Influence of School Administrator Leadership on Student Learning: The Role of Collective Teacher Efficiency as Mediator. National Management and Educational Seminar Proceeding. 
Hopkins, M. M., \& Yonker, R. D. (2015). Managing conflict with emotional intelligence: abilities that make a difference. Journal of Management Development, 34(2), 226-244.

Sani, M. I. \& Zaiton, M. N. (2001). School Management Faced by Newly Appointed Principal and Headmaster. $10^{\text {th }}$ National Management and Educational Seminar, 2001.

Mazalan, K. (2002). Transformative Leadership: New Rotric or Needs? $11^{\text {th }}$ National Leadership Management Proceeding.

Koh, W. L., Steers, R. M., \& Terborg, J. R. (1995). The effects of transformational leadership on teacher attitudes and student performance in Singapore, 16(June 1993), 319-334.

KPM. (2013). Malaysia Education Blueprint 2013 - 2025.

Naseer, Z., Chishti, S., Rahman, F., \& Jumani, N. B. (2011). Impact of Emotional Intelligence on Team Performance in Higher Education Institutes, 3(1), 30-46.

Sagnak, M. (2010). The Relationship Between Transformational School Leadership and Ethical Climate. Educational SciencesTheory \& Practice, 10(2).

Amin, S. B. (2012). Rethinking of Leadership Development. Journal of Public Management. 55-68.

Sidhu, G. K., \& Fook, C. Y. (2005). Investigating Leadership Characteristic Of Excellent Principle in Malaysia. In Aspiring For School Excellence and Best Practices for School Leadership.

Ishak, S. B. (2002). Favors Leadership Style: Hypothecal Case. $11^{\text {th }}$ National Management and Educational Seminar.

Stokely, D. R. (2008). A Correlational Study of El and Successful Leadership in the Retail Industry.

Tabor, U. Bin. (1998). Principal Leadership and School Effectiveness: Case Study in SAratok, Sarawak. $k$.

Tang, H.-W. V., Yin, M.-S., \& Nelson, D. B. (2010). The relationship between emotional intelligence and leadership practices: A cross-cultural study of academic leaders in Taiwan and the USA. Journal of Managerial Psychology, 25,

Wendorf-heldt, K. K., \& Kay, K. (2009). Emotional intelligence: The link to school leadership practices that increase student achievement .

Nazri, M. Z. (2012). Quality Leadership Through Ministry Novel. 